\title{
Studies on Thermal and Morphological Properties of Polyurethane Foam Filled Polypropylene/Poly(lactic acid) Blends
}

\author{
Naile Angın1 ${ }^{\text {iD }}$, Sena Çaylak ${ }^{2}$ iD, Murat Ertaş 1*iD \\ 1 Department of Forest Industry Engineering, Faculty of Forestry, Bursa Technical University, 16310 Bursa, Turkey \\ 2 Department of Biocomposite Engineering, Bursa Technical University, 16310 Bursa, Turkey
}

Cite this paper as:

Angın, N., Çaylak,S., Ertaş, M. (2019). Studies on Thermal and Morphological Properties of Polyurethane Foam Filled Polypropylene/Poly(lactic acid) Blends. Journal of Innovative Science and Engineering. 3(2): 47-56

*Corresponding author: Murat ERTAŞ E-mail: murat.ertas@btu.edu.tr Tel: +90 (224) 3003562

Received Date: 04/12/2019

Accepted Date: 16/12/2019

(C) Copyright 2019 by

Bursa Technical University. Available online at http://jise.btu.edu.tr/

\section{(c) (i) (9)}

The works published in Journal of Innovative Science and Engineering (JISE) are licensed under a Creative Commons Attribution-NonCommercial 4.0 International License.

\begin{abstract}
Polyurethane foams are used in many different applications, such as insulation and coating materials, packaging, furniture and so on. It has very low weight, low cost and thermal conductivity hereby frequently preferred by architectural and construction industry. On the other hand, these large-scale uses bring with waste problem after applications. In this study, the effect of polyurethane foam waste (PUw) on the thermal and morphological properties of polypropylene (PP)/ poly(lactic acid) (PLA) composites plasticized with polyethylene glycol (PEG 400) was investigated. PUw filled PP/PLA composites were prepared using melt blending followed by compression molding. Thermal and morphological properties of PUw filled PP/PLA composites were characterized by thermogravimetric analysis (TGA), differential scanning calorimetry (DSC), thermal conductivity analyzer and scanning electron microscopy (SEM). The results shown that the thermal conductivity of the composites improved significantly with addition of $\mathrm{PUw}$, while glass transition temperature $\left(\mathrm{T}_{\mathrm{g}}\right)$, the melting temperature $\left(\mathrm{T}_{\mathrm{m}}\right)$ and melting enthalpy $\left(\Delta \mathrm{H}_{\mathrm{m}}\right)$ values of the composites decreased. Based on finding, the PUw could be used as filler in PP/PLA composites for insulation and energy efficiency.
\end{abstract}

Keywords: Polyurethane foam, Polylactic acid, Polypropylene, Thermal properties, Thermal conductivity 


\section{Introduction}

Composite materials have an important place in many engineering applications due to their advantages and diversity. Engineering materials should have different properties depending on the its place of use, and it is expected that the basic properties such as strength, flexibility, lightness, resistance to environmental conditions (moisture, UV etc.), thermal resistance and chemical resistance be also good. However it is rare to find all these expected properties in a single material. Composite materials, which started to be produced as alternative materials since the 1950s, have begun to be the solution to the difficulty about material supply which has different features together [1-6].

On the other hand, it is known that frequently used petroleum-based plastics and composites raise severe environmental problems. The petroleum-based materials decompose a long time and causes great harm to both nature and human health. Therefore, the demand for biodegradable and rapidly degrading products in nature has increased [7-10].

PLA is a biodegradable, thermoplastic and aliphatic polyester obtained from 100\% renewable sources such as corn, wheat and sugar cane. [11-12]. It is frequently preferred in composite manufacturing because of being completely biodegradable material. Due to the fact that it is easily available in the market and has a relatively low price, it has the highest potential usage in automotive, packaging and medical applications among biopolyesters [13-14]. Despite these good properties, it is known that PLA does not have high mechanical and thermal properties. In order to improve the thermal behavior of polymer-based materials such PLA and Polypropylene and to reduce their costs, a large amount of additive materials and energy are used in composite manufacturing [15-17].

Polyurethane foam is used frequently in automotive and construction sector as insulation material due to its low thermal conductivity and low density. The main purpose of thermal insulation products is to increase the heat conduction resistance of building elements. Therefore, the thermal conductivity coefficients determine the efficiency of the insulation property of such kind of products [18-21]. According to the International Organization for Standardization (ISO) and European Committee for Standardization (CEN) standards, the thermal conductivity of thermal insulation materials should be less than $0.065 \mathrm{~W} / \mathrm{mK}$. Insulation materials provide significant energy efficiency in terms of their main functions and thus significantly reduce the pollution occurred by energy production that causes climate change. In addition, huge amounts of raw materials, water, energy and chemicals are consumed during the production phase of the insulation materials and thus leads to waste and waste water generation. Especially polyurethane foams are easily turn into idle solid wastes that are expected to be recycled after they are used for siding [22-25].

Reuse of industrial wastes in different areas and minimizing their damages to the environment has been an important research topic in recent years. Value added, ecofriendly composites bring great importance to the composite material world. Renewable, bio materials also minimize carbon dioxide emission and world's leading industries and manufacturers looking for sustainable and energy saving materials to reduce their environmental footprint [26-29]. In this study, PP and PLA have been used together with polyurethane foam wastes in order to obtain energy saving, superior thermal properties by reducing their disadvantages. 


\section{Materials and Methods}

\subsection{Materials}

The polypropylene (PP) was supplied by Petkim Petrochemical Company in Izmir, Turkey with a density of 0.905 $\mathrm{g} / \mathrm{cm} 3$, melting point of $163^{\circ} \mathrm{C}$ and melt flow index of $4.7 \mathrm{~g} / 10 \mathrm{~min}$. PLA (Luminy ${ }^{\circledR}$ LX175, Total Corbion, Holland) with a melt flow index of $8 \mathrm{~g} / 10 \mathrm{~min}\left(2.16 \mathrm{~kg}\right.$ at $\left.210^{\circ} \mathrm{C}\right)$ and density of $1.24 \mathrm{~g} / \mathrm{cm}^{3}$ was used in this study. Polyurethane foam wastes (PUw) and Polyethylene glycol (PEG 400) was kindly supplied by Nuh-Pol, Turkey.

\subsection{Samples Preparation}

PLA, PP and PU were ground and dried in a conventional air oven. PEG 400 into polymer matrix was kept constant at 20 wt.\% of total composite. All parameter details are shown in Table 1. Depending on the extruding process, oven dried materials were mixed for $5 \mathrm{~min}$ and fed into the hopper of a twin-screw extruder (L/D 40, Gülnar Makine Ltd., Turkey). The screw speed and temperatures of extruder barrel were set as $40 \mathrm{rpm}$ and at $160{ }^{\circ} \mathrm{C}, 170{ }^{\circ} \mathrm{C}, 180{ }^{\circ} \mathrm{C}, 190{ }^{\circ} \mathrm{C}$, and 190 ${ }^{\circ} \mathrm{C}$, respectively. The temperature of the extruder die zone was kept at $200{ }^{\circ} \mathrm{C}$. The composite blends were granulated after the extrusion. Oven-dried and granulated samples were molded using hot press (Carver Inc., USA) with pressure of $0.24 \mathrm{MPa}$ and temperature of $190^{\circ} \mathrm{C}$ pressed for $5 \mathrm{~min}$. Composites were prepared and cut for thermal tests according to the standards with laser cutting device.

Table 1. Material designation and composition of the PUw filled PP/PLA composites.

\begin{tabular}{llllc}
\hline ID & $\begin{array}{l}\text { PLA } \\
(\text { wt.\% })\end{array}$ & $\begin{array}{l}\text { PP } \\
(\text { wt.\% })\end{array}$ & $\begin{array}{l}\text { PUw } \\
(\text { wt.\% })\end{array}$ & $\begin{array}{l}\text { PEG 400 } \\
(\text { wt.\% })\end{array}$ \\
\hline PLA & 100 & - & - & - \\
PP & 100 & - & - & - \\
PP/PUw1 & - & 50 & 30 & 20 \\
PP/PLA/PUw2 & 10 & 40 & 30 & 20 \\
PP/PLA/PUw3 & 20 & 30 & 30 & 20 \\
PP/PLA/PUw4 & 25 & 25 & 30 & 20 \\
\hline
\end{tabular}

\subsection{Differential scanning calorimetry analysis (DSC)}

DSC analyses were carried out using differential scanning calorimeter (TA Instruments, USA) under an inert gas $\left(\mathrm{N}_{2}\right)$ flow rate of $100 \mathrm{~mL} / \mathrm{min}$ accordingly ASTM D3418 to determine the melting, crystallization and glass transition temperatures of the samples. Each sample in an aluminum pan were heated from $21^{\circ} \mathrm{C}$ to $200^{\circ} \mathrm{C}$ at a heating rate of 10 ${ }^{\circ} \mathrm{C} / \mathrm{min}$ and cooled to room temperature at the same speed. The results were calculated as the average for tested samples. The melting temperature $\left(\mathrm{T}_{\mathrm{m}}\right)$, glass transition temperature $\left(\mathrm{T}_{\mathrm{g}}\right)$ and cold crystallization temperature $\left(\mathrm{T}_{\mathrm{cc}}\right)$ of the samples were determined. The PUw filled PP/PLA composites' degree of crystallinity $\left(\mathrm{X}_{\mathrm{c}}\right)$ was calculated with respect to Eq.1 [30]: 


$$
X_{c}(\%)=\frac{\Delta H_{m}-\Delta H_{c c}}{w P P \times \Delta H_{m P L A}+w P L A \times \Delta H_{m P L A}} \times 100
$$

where $\triangle H_{m}$ is measured melting and $\triangle H_{c c}$ is the cold crytstallization enthalpies, $\triangle H_{m P P}$ and $\triangle H_{m P L A}$ are the melting enthalpy of pure polymer with $100 \%$ crystallinity (188.9 and $93.6 \mathrm{~J} / \mathrm{g}$, respectively) [31-32]. $\mathrm{W}$ is referring the amount of weight fraction of PP and PLA in the sample.

\subsection{Thermogravimetric analysis (TGA)}

Thermogravimetric analysis was carried out to determine the thermal stability, decomposition temperature and mechanism of the composites by using thermogravimetric analyzer (Hitachi Hi-Tech STA7200, Japan). During analysis, samples were heated from $30^{\circ} \mathrm{C}$ to $800{ }^{\circ} \mathrm{C}$ with a heating rate of $10^{\circ} \mathrm{C} / \mathrm{min}$ and under $\mathrm{N}_{2}$ atmosphere $(200 \mathrm{ml} / \mathrm{min})$.

\subsection{Thermal conductivity analysis}

Thermal conductivity of the samples was measured using FOX 314 Laser Comp thermal conductivity meter (TA Instruments, USA) according to ASTM C-518 with a size of $10 \times 10 \times 1 \mathrm{~cm}$. During analysis, the temperatures of bottom and top plates were set to $10{ }^{\circ} \mathrm{C}$ and $30{ }^{\circ} \mathrm{C}$, respectively.

\subsection{Scanning electron microscopy (SEM) analysis}

The effect of the change in the structure and the changing morphology in the surface and intermediate sections of the composite samples was observed by scanning electron microscopy (SEM) (Carl Zeiss / Gemini 300, Germany) under an acceleration voltage of $10 \mathrm{kV}$. The fractured surface of sample was covered with gold under vacuum before scanning.

\section{Results and Discussion}

\subsection{Differential scanning calorimetry (DSC)}

Figure 1 shows the DSC thermograms of the PUw filled PP/PLA composites, and the results obtained from DSC curves are given in Table 2. The melting temperature $\left(\mathrm{T}_{\mathrm{m}}\right)$, the cold crystallization temperature $\left(\mathrm{T}_{\mathrm{cc}}\right)$, and the degree of crystallinity $\left(\mathrm{X}_{\mathrm{c}}\right)$ of neat $\mathrm{PP}$ are $164.9^{\circ} \mathrm{C}, 114.1^{\circ} \mathrm{C}$, and $47.5 \%$, respectively.

When Polyurethane waste (PUw) is added to PP/PLA blend, the overall glass transition temperature $\left(\mathrm{T}_{\mathrm{g}}\right)$ decreases slightly as compared with neat PLA and PP (Table 2 and Figure 1). This case may be explained that the PUw decreases entanglements and interactions of polymer chain. DSC results show that the melting temperature $\left(\mathrm{T}_{\mathrm{m}}\right)$ and melting enthalpy $\left(\Delta \mathrm{H}_{\mathrm{m}}\right)$ values of the composites decrease with increasing of PLA content in comparison with neat PLA. In the crystalline/amorphous immiscible blend system the presence of separate domains of PLA (amorphous component) in the molten PP (crystalline component) during the crystallization process may cause a decrease of the measured $\mathrm{T}_{\mathrm{m}}$ [33]. As seen from Table 2 crystallinity $\left(\mathrm{X}_{\mathrm{c}}\right)$ of the melt blended samples value increases while the recrystallization of the polymer chains during the cooling part of the melt blending process. 
Table 2. DCS data of the PUw filled PP/PLA composites.

\begin{tabular}{|c|c|c|c|c|c|c|}
\hline \multirow[b]{2}{*}{ ID } & \multicolumn{3}{|l|}{ Melting } & \multicolumn{3}{|c|}{ Crystallization } \\
\hline & $\mathrm{T}_{\mathrm{g}}\left({ }^{\circ} \mathrm{C}\right)$ & $\mathrm{T}_{\mathrm{m}}\left({ }^{\circ} \mathrm{C}\right)$ & $\Delta \mathrm{H}_{\mathrm{m}}(\mathrm{J} / \mathrm{g})$ & $\mathrm{T}_{\mathrm{cc}}\left({ }^{\circ} \mathrm{C}\right)$ & $\Delta \mathrm{H}_{\mathrm{cc}}(\mathrm{J} / \mathrm{g})$ & $\mathrm{X}_{\mathrm{c}}(\%)$ \\
\hline Neat PLA & 65.7 & 174.7 & 49.2 & 96.7 & -11.0 & 6.8 \\
\hline Neat PP & - & 164.9 & 89.7 & 114.1 & - & 47.5 \\
\hline PP/PUw1 & 58.7 & 162.6 & 42.0 & 112.3 & -51.5 & 46.8 \\
\hline PP/PLA/PUw2 & 57.3 & 162.2 & 36.2 & 120.7 & -38.8 & 47.4 \\
\hline PP/PLA/PUw3 & 62.6 & 163.9 & 33.1 & 121.6 & -23.5 & 38.8 \\
\hline PP/PLA/PUw4 & 52.5 & 162.9 & 35.4 & 121.8 & -24.9 & 42.8 \\
\hline
\end{tabular}

Note. $\mathrm{T}_{\mathrm{g}}$ : glass transition temperature; $\mathrm{T}_{\mathrm{m}}$ : melting temperature; $\Delta \mathrm{H}_{\mathrm{m}}$ : enthalpy of melting; $\mathrm{T}_{\mathrm{cc}}$ : cold crystallization temperature; $\Delta \mathrm{H}_{\mathrm{cc}}$ : enthalpy of crystallization; $\mathrm{X}_{\mathrm{c}}$ : crystallinity

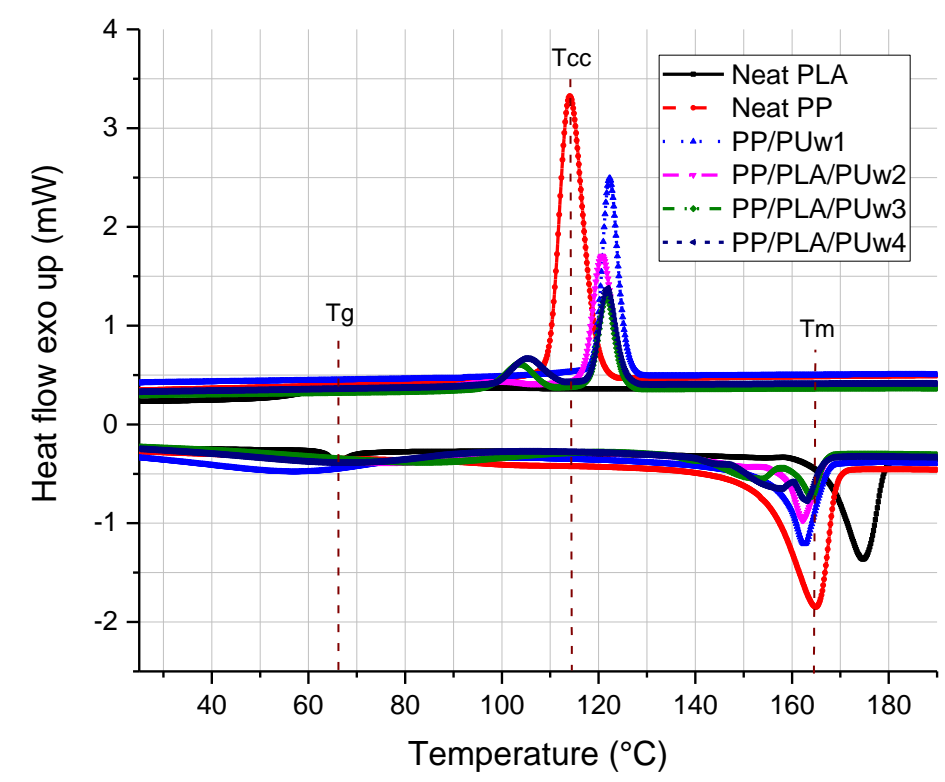

Figure 1. DSC thermograms of the PUw filled PP/PLA composites

\subsection{Thermogravimetric analysis (TGA)}

The TGA and DTG thermograms of the PUw filled PP/PLA composites under an inert atmosphere are shown in Figure 2. In addition, the thermal degradation of the PUw filled PP/PLA composites are summarized in Table 3 summarizes. The T5\% and T10\% refer to the degradation temperatures at $5 \mathrm{wt} . \%$ and $10 \mathrm{wt} . \%$ weight loss, respectively. Also, the Tmax corresponds to the temperature of the maximum rate of thermal degradation. 

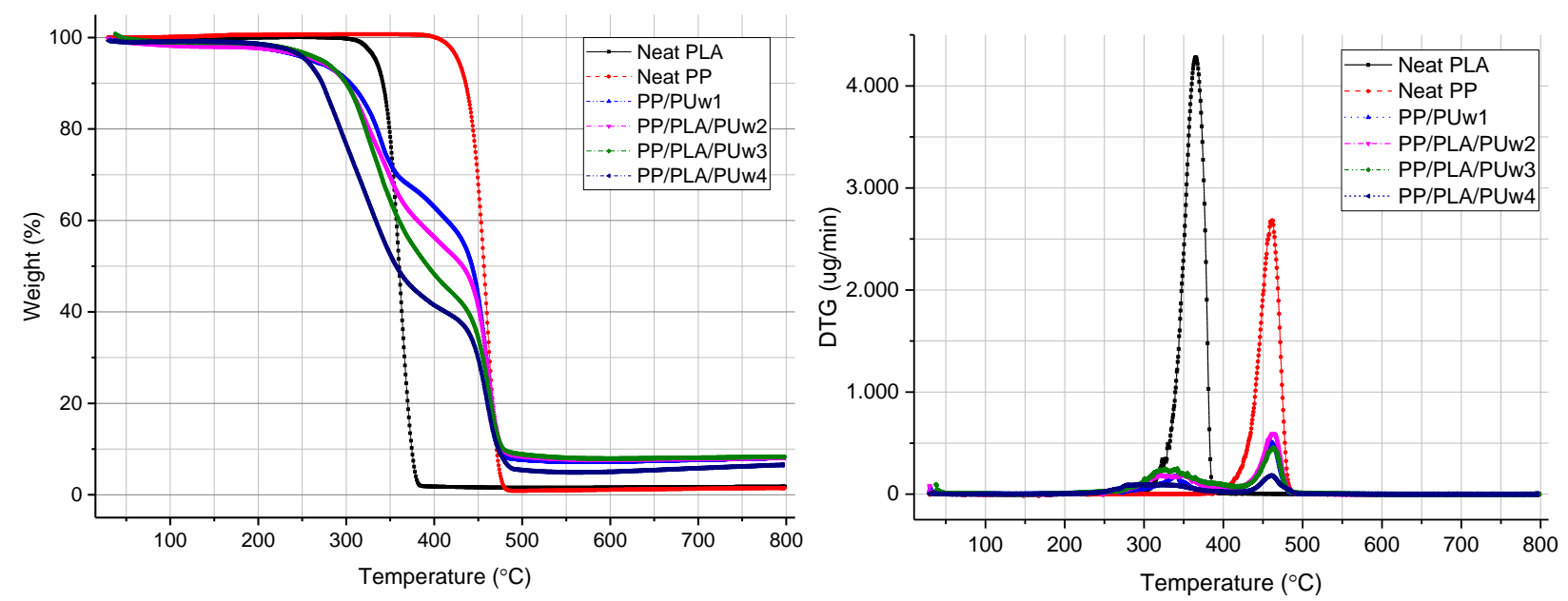

Figure 2. TGA and DTG curves of the PUw filled PP/PLA composites

In contrast to the neat PP and PLA, two-step degradation process in polymer matrix was clearly seen in PUw filled PP/PLA blends. The percentage weight loss in the first and second degradation step related to the amount of PLA, PP and PUw. PP was more stable than PLA, which T5\% of PP was $433^{\circ} \mathrm{C}$ whereas T5\% of PLA was $348{ }^{\circ} \mathrm{C}$. It was detected that blending of PP and PLA resulted in an improvement in the thermal stability. However, there were no significant changes in $\mathrm{T}_{\max }$ with varying of PP/PLA blend ratios. The temperature of the maximum rate of degradation of PP/PLA blends exhibited a slightly changes depending on the addition of PUw as well. Also, char residue at $800{ }^{\circ} \mathrm{C}$ significantly increased with addition of PUw, which points out more char and more compact layer are formed under high temperature conditions.

Table 3. TGA and DTG data of the PUw filled PP/PLA composites.

\begin{tabular}{ccccc}
\hline ID & $\mathrm{T}_{5 \%}\left({ }^{\circ} \mathrm{C}\right)$ & $\mathrm{T}_{10 \%}\left({ }^{\circ} \mathrm{C}\right)$ & $\mathrm{T}_{\max }\left({ }^{\circ} \mathrm{C}\right)$ & Residue at 800 (wt.\%) \\
\hline Neat PLA & 348.4 & 365.0 & 368.9 & 1.9 \\
Neat PP & 433.1 & 457.3 & 461.5 & 1.5 \\
PP/PUw1 & 309.6 & 423.4 & 460.5 & 7.9 \\
PP/PLA/PUw2 & 308.5 & 417.7 & 463.6 & 7.9 \\
PP/PLA/PUw3 & 309.3 & 399.5 & 464.1 & 8.0 \\
PP/PLA/PUw4 & 310.9 & 391.2 & 457.2 & 8.1 \\
\hline
\end{tabular}

\subsection{Thermal Conductivity}

Thermal conductivity coefficient of the samples is shown in Figure 3. As can be seen from Figure 3, the thermal conductivity coefficient of the neat PP, PLA and PUw were $0.184,0.132$ and $0.033 \mathrm{~W} / \mathrm{mK}$. The thermal conductivity coefficients of PP/PLA composites considerably decreased with addition of PUw, which play a critical role in the improvement of insulation properties of materials. 


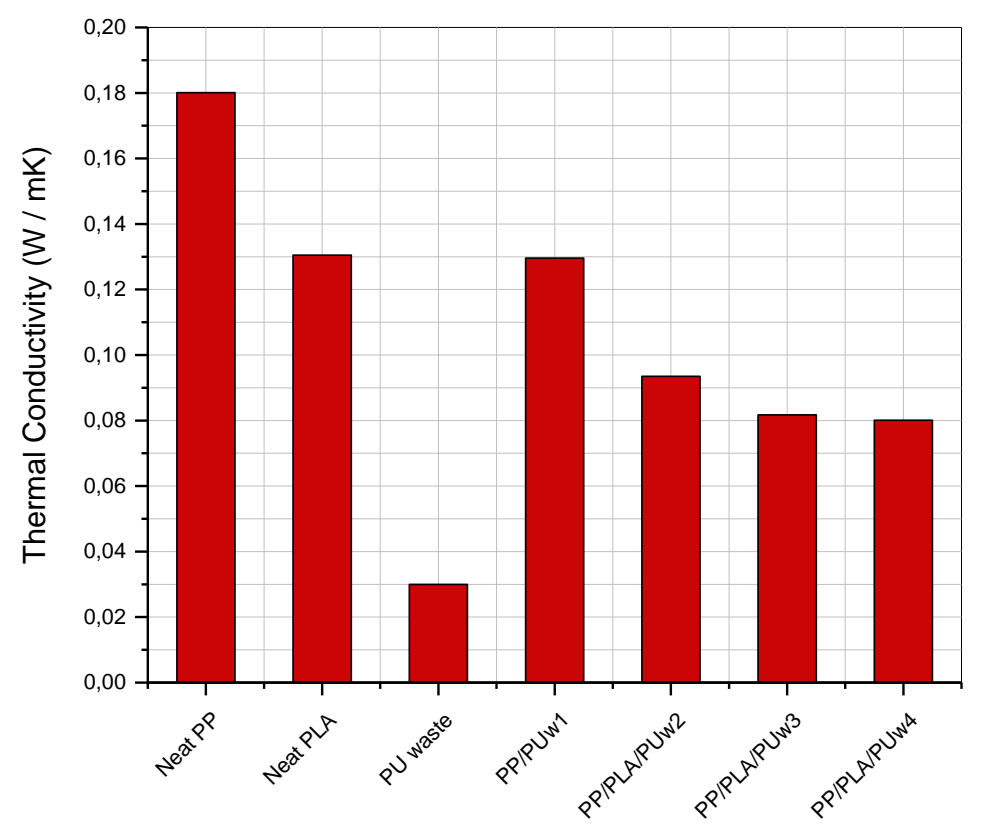

Figure 3. Thermal conductivity coefficients of the PUw filled PP/PLA composites.

\subsection{Scanning electron microscope (SEM)}

Figure 4 shows the micrographs of the composites and marked PUw particles. As can be seen from Figure 4, PUw particles clung on the composite surface due to different PLA ratio in composite matrix. It was seen that the PUw completely embeds into polymer blends matrix, and it decreases interfacial gaps in the polymer blend.
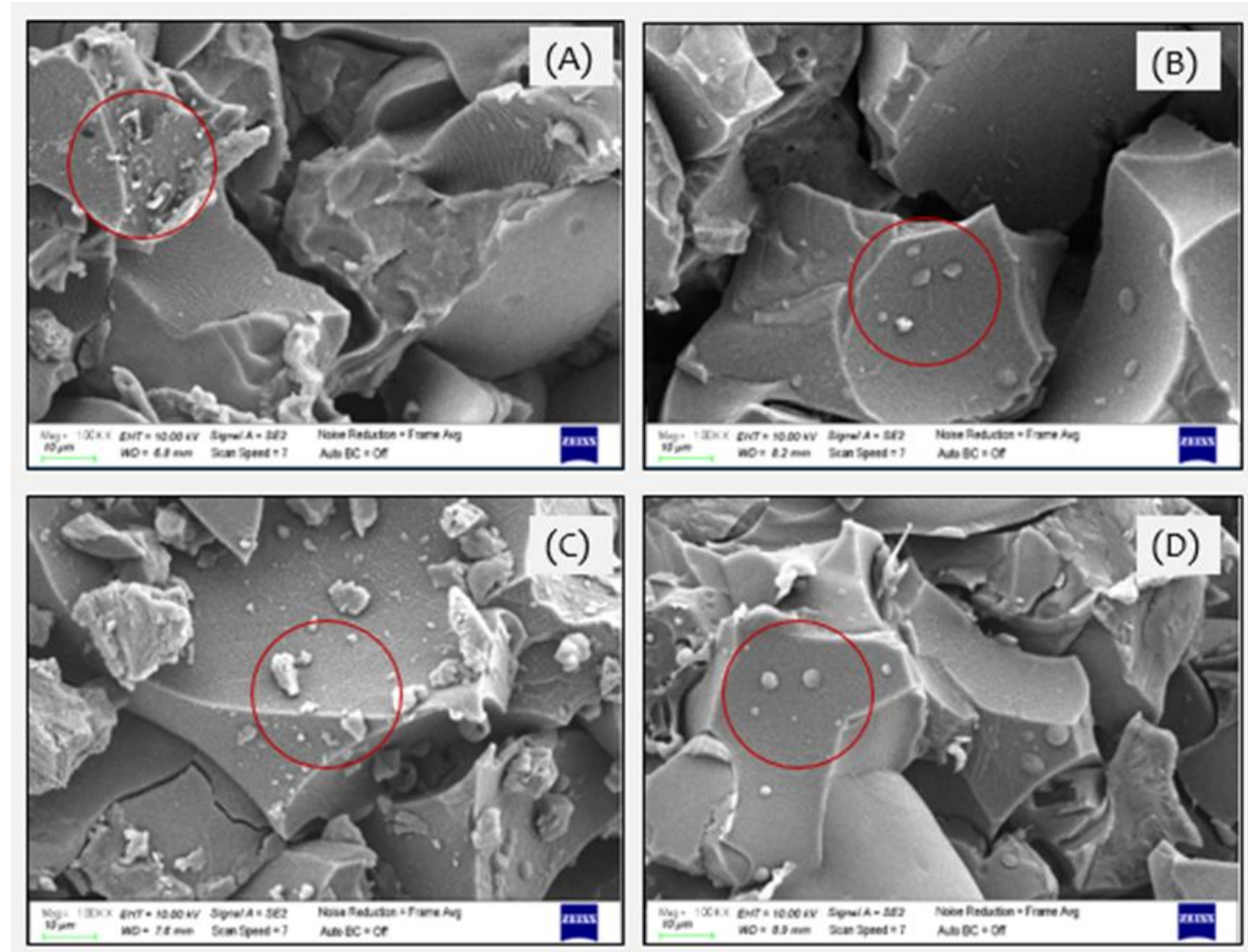

Figure 4. SEM micrographs of the fractured surface of the PUw filled PP/PLA composites under $x 1000$ magnification: (A) PP/PUw1; (B) PP/PLA/PUw2; (C) PP/PLA/PUw3; (D) PP/PLA/PUw4 


\section{Conclusion}

PUw filled PP/PLA composites plasticized with PEG 400 were successfully succeeded by melt blending process. DSC thermograms revealed that the crystallinity values of the composites slightly decreased by increase of PLA loading and addition of PUw compared with pure PP. TGA results suggested that blending of PP and PLA resulted in an improvement in the thermal stability, and char residue at $800^{\circ} \mathrm{C}$ significantly increased with addition of PUw.

PUw filled PP/PLA composites plasticized with PEG 400 were successfully succeeded by melt blending process. DSC thermograms revealed that the crystallinity values of the composites slightly decreased by increase of PLA loading and addition of PUw compared with pure PP. TGA results suggested that blending of PP and PLA resulted in an improvement in the thermal stability, and char residue at $800{ }^{\circ} \mathrm{C}$ significantly increased with addition of PUw.

\section{Acknowledgments}

A preliminary version of this paper is partially presented at the 3rd International Mediterranean Forest and Environment Symposium, Kahramanmaras, October 2019. The authors are grateful to NuhPol for PEG 400 and polyurethane foam waste samples supply.

\section{References}

[1] Ertas, M., Altuntas, E. and Donmez Cavdar, A. (2019). Effects of halloysite nanotube on the performance of natural fiber filled poly (lactic acid) composites. Polymer Composites, 40:4238-4247

[2] Bulut, Y., Erdoğan, Ü. H. (2011). Selüloz Esaslı Doğal Liflerin Kompozit Üretiminde Takviye Materyali Olarak Kullanımı. Tekstil ve Mühendis, 18: 82-85.

[3] Mohanty, A. K., Misra, M. A. and Hinrichsen, G. I. (2000). Biofibres, biodegradable polymers and biocomposites: An overview. Macromolecular materials and Engineering, 276(1): 1-24.

[4] Hong, C. K., Hwang, I., Kim, N., Park, D. H., Hwang, B. S. and Nah, C. (2008). Mechanical properties of silanized jute-polypropylene composites. Journal of Industrial and Engineering Chemistry, 14(1): 71-76.

[5] García, M., Garmendia, I. and García, J. (2008). Influence of natural fiber type in eco-composites. Journal of Applied Polymer Science, 107(5): 2994-3004.

[6] Oksman, K., Skrifvars, M. and Selin, J. F. (2003). Natural fibres as reinforcement in polylactic acid (PLA) composites. Composites science and technology, 63(9): 1317-1324.

[7] De Silva, R. T., Pasbakhsh, P., Goh, K. L., Chai, S. P. and Chen, J. (2014). Synthesis and characterisation of poly (lactic acid)/halloysite bionanocomposite films. Journal of Composite Materials, 48(30): 3705-3717.

[8] Krishnaiah, P., Ratnam, C. T. and Manickam, S. (2017). Development of silane grafted halloysite nanotube reinforced polylactide nanocomposites for the enhancement of mechanical, thermal and dynamic-mechanical properties. Applied Clay Science, 135: 583-595.

[9] Sangeetha, V. H., Deka, H., Varghese, T. O. and Nayak, S. K. (2018). State of the art and future prospectives of poly (lactic acid) based blends and composites. Polymer composites, 39(1): 81-101.

[10] Dorgan, J. R. (1999). Poly (lactic acid) properties and prospects of an environmentally benign plastic. In 3rd Annual Green Chemistry and Engineering Conference Proceedings 99:145-149. 
[11] Ren, J. (2010). Modification of PLA. In Biodegradable Poly (Lactic Acid): Synthesis, Modification, Processing and Applications, Springer Berlin Heidelberg, Germany. pp 38-141. ISBN: 978-3-642-17596-1

[12] Chiellini, E., Covolan, V. L., Orsini, L. M. and Solaro, R. (2003). Polymeric nanoparticles based on polylactide and related copolymers. In Macromolecular Symposia, 197(1): 345-354.

[13] Ashori, A. (2008). Wood-plastic composites as promising green-composites for automotive industries. Bioresource technology, 99(11): 4661-4667.

[14] Hartmann, M. H. (1998). High molecular weight polylactic acid polymers. In Biopolymers from renewable resources Springer, Berlin, Heidelberg. Germany. pp. 367-411. ISBN: 978-3-662-03680-8

[15] Drumright, E. Gruber, R. and Henton E. (2000). Polylactic acid technology, Advanced Materials, 12: 1841 1846.

[16] Rajan, K. P., Thomas, S. P., Gopanna, A., Al-Ghamdi, A. And Chavali, M. (2018). Rheology, mechanical properties and thermal degradation kinetics of polypropylene (PP) and polylactic acid (PLA) blends. Materials Research Express, 5(8): 085304.

[17] Pivsa-Art, S., Kord-Sa-Ard, J., Pivsa-Art, W., Wongpajan, R., Narongchai, O., Pavasupree, S. and Hamada, H. (2016). Effect of compatibilizer on PLA/PP blend for injection molding. Energy Procedia, 89: 353-360.

[18] Yurtseven, R., Tarakçılar, A. and Topçu, M. (2013). Dolgu Maddesi Olarak Kullanılan Farklı Uçucu Küllerin Sert Poliüretan Köpük Malzemelerin Mekanik Özellikleri İle Isıl Ve Yanma Davranışları Üzerine Etkileri. Gazi Üniversitesi Mühendislik-Mimarlık Fakültesi Dergisi, 28(4).

[19] Ubowska, A. (2010). Montmorillonite as a polyurethane foams flame retardant. Archivum Combustionis, 30(4): 459-462.

[20] Goods, S. H., Neuschwanger, C. L., Whinnery, L. L. and Nix, W. D. (1999). Mechanical properties of a particlestrengthened polyurethane foam. Journal of Applied Polymer Science, 74(11): 2724-2736.

[21] Wang, J. Q. and Chow, W. K. (2005). A brief review on fire retardants for polymeric foams. Journal of applied polymer science, 97(1): 366-376.

[22] Romero-Ibarra, I. C., Bonilla-Blancas, E., Sanchez-Solis, A. and Manero, O. (2012). Influence of the morphology of barium sulfate nanofibers and nanospheres on the physical properties of polyurethane nanocomposites. European Polymer Journal, 48(4): 670-676.

[23] Saha, M. C., Kabir, M. E., \& Jeelani, S. (2008). Enhancement in thermal and mechanical properties of polyurethane foam infused with nanoparticles. Materials Science and Engineering: 479(1-2): 213-222.

[24] Saint-Michel, F., Chazeau, L. and Cavaillé, J. Y. (2006). Mechanical properties of high density polyurethane foams: II Effect of the filler size. Composites Science and Technology, 66(15): 2709-2718.

[25] Aydoğan, B. and Usta, N. (2015). Nanokil ve Kabaran Alev Geciktirici ilavesinin Rijit Poliüretan Köpük Malzemelerin 1sıl bozunma ve yanma davranışlarına etkilerinin incelenmesi. Gazi Üniversitesi MühendislikMimarlık Fakültesi Dergisi, 30(1): 9-18.

[26] Yu, L., Dean, K. and Li, L. (2006). Polymer blends and composites from renewable resources. Progress in polymer science, 31(6): 576-602.

[27] Mohanty, A. K., Misra, M. and Drzal, L. T. (2002). Sustainable bio-composites from renewable resources: opportunities and challenges in the green materials world. Journal of Polymers and the Environment, 10(1-2): 19-26. 
[28] Zhang, M. Q., Rong, M. Z. and Lu, X. (2005). Fully biodegradable natural fiber composites from renewable resources: all-plant fiber composites. Composites Science and Technology, 65(15-16): 2514-2525.

[29] Nyambo, C., Mohanty, A. K. and Misra, M. (2010). Polylactide-based renewable green composites from agricultural residues and their hybrids. Biomacromolecules, 11(6):1654-1660.

[30] Chow, W. S., Tham, W. L., Poh, B. T. and Ishak, Z. M. (2018). Mechanical and thermal oxidation behavior of poly (Lactic Acid)/halloysite nanotube nanocomposites containing N, N'-Ethylenebis (Stearamide) and SEBSg-MA. Journal of Polymers and the Environment, 26(7): 2973-2982.

[31] Ndazi, B. S. And Karlsson, S. (2011). Characterization of hydrolytic degradation of polylactic acid/rice hulls composites in water at different temperatures. Express Polymer Letters, 5(2).

[32] Quero, E., Müller, A. J., Signori, F., Coltelli, M. B. and Bronco, S. (2012). Isothermal Cold-Crystallization of PLA/PBAT Blends With and Without the Addition of Acetyl Tributyl Citrate. Macromolecular Chemistry and Physics, 213(1): 36-48.

[33] Ploypetchara, N., Suppakul, P., Atong, D. And Pechyen, C. (2014). Blend of polypropylene/poly (lactic acid) for medical packaging application: physicochemical, thermal, mechanical, and barrier properties. Energy Procedia, 56: 201-210. 